\title{
PENERAPAN DIGITAL MARKETING DAN SISTEM INFORMASI AKUNTANSI BAGI UMKM DI WILAYAH KAMPUNG BARU JEMBER
}

\author{
Nurshadrina Kartika Sari ${ }^{1}$ \\ ${ }^{1}$ Jurusan Akuntansi, Sekolah Tinggi Ilmu Ekonomi Mandala \\ e-mail: shadrina.kartika@stie-mandala.ac.id
}

\begin{abstract}
UMKM merupakan sektor usaha yang dapat bergerak disegala macam bidang usaha, termasuk UMKM yang berada di wilayah Kampung Baru Jember. Mayoritas usaha yang dimiliki UMKM tersebut merupakan bisnis yang bergerak dibidang kuliner, diantaranya bisnis seafood, makanan rumahan dan minuman siap saji yang berbahan kopi dan cokelat. Sebelum terjadi pandemi COVID-19 bisnis yang dijalankan masih dikelola dengan model pemasaran sederhana dengan pencatatan keuangan tradisional. Selama pandemi COVID-19 jumlah penjualan harian UMKM menurun akibat dampak kekhawatiran masyarakat untuk mengkonsumsi makanan di luar rumah, sekalipun pemerintah telah menerapkan New Normal belum bisa mengembalikan jumlah penjualan UMKM. Tujuan khusus kegiatan PKM ini adalah: (1) UMKM di Wilayah Kampung Baru dapat mengimplementasikan Digital Marketing dan Sistem Informasi Akuntansi dan (2) Mampu mengimplementasikan Sistem Informasi Akuntansi untuk mempermudah proses pencatatan keuangan harian. Metode yang digunakan adalah penyuluhan kepada UMKM terkait Digital Marketing dan Sistem Informasi Akuntansi, pelatihan dan pendampingan dilakukan untuk mendorong dan memperkuat kemampuan UMKM. Pada program ini berhasil dibangun sistem penjualan dengan e-commerce dengan pemanfaatan Digital Marketing dan sistem informasi akuntansi untuk pencatatan keuangan.
\end{abstract}

Keywords : UMKM, Digital Marketing, Sistem Informasi Akuntansi

\section{PENDAHULUAN \\ Analisis Situasi}

Usaha Mikro, Kecil dan Menengah (UMKM) merupakan usaha produktif milik orang perorangan dan/atau badan usaha perorangan yang memiliki kriteria usaha mikro sebagaimana diatur dalam Undang-Undang (UU) Republik Indonesia Nomor 20 Tahun 2008 tentang UMKM. Kriteria sebuah usaha dikatakan UMKM salah satunya dengan menggunakan satuan moneter dimana usaha mikro memiliki aset paling banyak Rp 50 juta tidak termasuk tanah dan bangunan dengan hasil penjualan maksimal Rp 300 juta, usaha kecil memiliki aset Rp 50 juta sampai dengan Rp 500 juta dengan hasil penjualan antara Rp 300 juta hingga Rp 2,5 M, dan usaha menengah memiliki aset antara Rp 500 juta hingga Rp $10 \mathrm{M}$ dan hasil penjualan lebih dari Rp 2,5 M hingga Rp $50 \mathrm{M}$. 
UMKM wilayah Kampung Baru atau mitra program pengabdian kepada masyarakat ini berada di Jalan Wijaya Kusuma, Kecamatan Patrang, Kabupaten Jember. Terdiri dari 12 UMKM yang bergerak dalam bisnis kuliner dengan wilayah penjualan adalah di Kecamatan Patrang dan Sumbersari. Mitra memiliki bisnis yang dilakukan warga untuk memenuhi kebutuhan sehari-hari maupun untuk membantu kepala rumah tangga.

Selama pandemi COVID-19 yang mulai merebak pada awal tahun 2020, hampir semua sektor terdampak termasuk UMKM. Penurunan penjualan semakin tajam akibat imbas dari diperlakukannya PSBB diberbagai wilayah, termasuk Kabupaten Jember. Secara tidak langsung konsumen UMKM mulai mengurangi aktivitas diluar rumah, termasuk pembelian produk-produk UMKM seperti makanan-minuman, bahkan salah satu mitra yang memiliki bisnis lembaga belajar-pun turut merasakan dampaknya.

Mitra hanya memproduksi produk mereka dan menjualnya secara langsung kepada konsumen, sebagian telah menggunakan sistem could kitchen dengan memanfaatkan jasa pengiriman daring seperti Gofood dan Grab Food. Sedangkan untuk pencatatan keuangan mitra hanya memanfaatkan perhitungan manual, sehingga untuk memperoleh informasi sebagai pengambilan keputusan terkait strategi pemasaran menjadi sulit.

\section{Permasalahan Mitra}

Berdasarkan analisis situasi diatas beberapa masalah yang dihadapi mitra dan ingin diselesaikan pada program pengabdian kepada masyarakat ini adalah sebagai berikut:

Aspek Sistem Digital Marketing. Penurunan jumlah konsumen/ pelanggan bagi bisnis yang dijalankan mitra, memaksa mitra untuk mulai beradaptasi dengan penggunaan media digital untuk mempermudah mitra dalam memperoleh dan melayani permintaan konsumen. Konsumen/ pelanggan yang enggan melakukan kegiatan di luar rumah, membuat mitra harus mulai menjemput bola untuk bisa menaikkan jumlah penjualannya kembali. Beberapa mitra memang telah menggunakan media promosi digital seperti Whatsapp, Instagram, Facebook, Google Bisnisku, Google Ads maupun Aplikasi pengiriman barang secara daring, namun penggunaannya perlu dimaksimalkan untuk dapat mengoptimalkan manfaatnya bagi mitra. Tidak sedikit mitra yang masih belum familiar dengan berbagai media tersebut, sehingga perlu adanya sosialisasi, pelatihan hingga pendampingan untuk memaksimalkan manfaat dari digital marketing tersebut.

Aspek Sistem Informasi Akuntansi. Mitra dalam mengelola keuangan bisnisnya hanya mencatat secara sederhana, bahkan ada yang tidak memisahkan pengeluaran dan pemasukkan dari kegiatan bisnisnya dengan keperluan rumah tangga. Beberapa mitra mengeluh dikala pandemi mereka yang telah memiliki hutang dengan asumsi penerimaan dari bisnis mereka mampu memenuhi hutang tersebut, ketika pandemi berlangsung bisnis mitra lesu dan tuntutan hutang dan pemenuhan kebutuhan sehari-hari 
akhirnya terhambat. Bila mitra memperhitungkan dan mencatat proses bisnis dengan baik akan mampu merencanakan kegiatan bisnisnya lebih terarah dan terukur. Untuk menyelesaikan permasalahan tersebut program ini memberikan pelatihan dan pendampingan terkait sistem informasi akuntansi mulai dari penyusunan transaksi harian hingga laporan keuangan dengan bantuan aplikasi Micosoft Excel.

\section{METODE}

Metode pelaksanaan yang dilakukan dalam program ini adalah (1) tahap persiapan melalui koordinasi tim dan mitra, (2) tahap pelaksanaan untuk mengatasi aspek sistem Digital Marketing melalui pelaksanaan program pelatihan terkait sosalisasi dan pendaftaran pada e-commerce dan market place, penyusunan konten pemasaran digital yang menarik, pelatihan penguatan brand produk dan pendampingan dalam pemanfaatan media sosial untuk promosi bisni, (3) tahap pelaksanaan untuk mengatasi aspek sistem informasi akuntansi dengan pelatihan dan pendampinyan mulai dari penyusunan alur akuntansi bagi bisnis mitra, pelatihan pencatatan akuntansi hingga pelaporan keuangan menggunakan Microsoft Excel, (4) tahapan monitoring dan evaluasi dilaksanakan untuk memastikan bahwa sistem digital marketing dan sistem informasi akuntansi dapat berjalan dengan baik bagi mitra, meskipun telah selesai program ini.

\section{HASIL DAN PEMBAHASAN}

Hasil kegiatan program ini adalah (1) hasil kegiatan untuk aspek Digital Marketing adalah telah diselenggarakan sosialisasi materi terkait dengan pemanfaatan digital marketing bagi UMKM dan pendampingan sistem pemasaran digital yang terdiri dari pendaftaran bisnis mitra di Google Bisnisku dan market place seperti Grab Food, Go Food dan Shoope, pelatihan penyusunan materi promosi yang terjadwal di media sosial mitra dan pelaksanaan strategi promosi dengan pemberian masker dan penyediaan hand sanitizer sebagai bentuk keperdulian mitra terhadap pelanggan, (2) hasil kegiatan untuk aspek sistem informasi akuntansi adalah sosialisasi tentang pembuatan prosedur/alur akuntansi yang sesuai dengan bisnis mitra dan pendampingan pencatatan transaksi awal hingga pelaporan keuangan melalui penggunaan Microsoft Excel. 


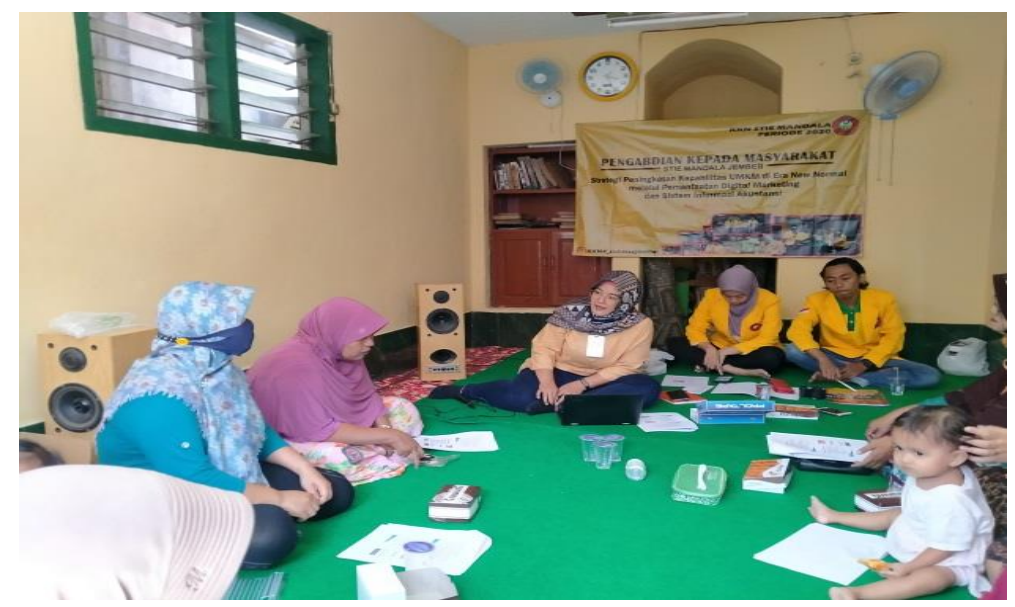

Gambar 1. Sosialisasi bersama mitra

Sumber : Penulis, 2020

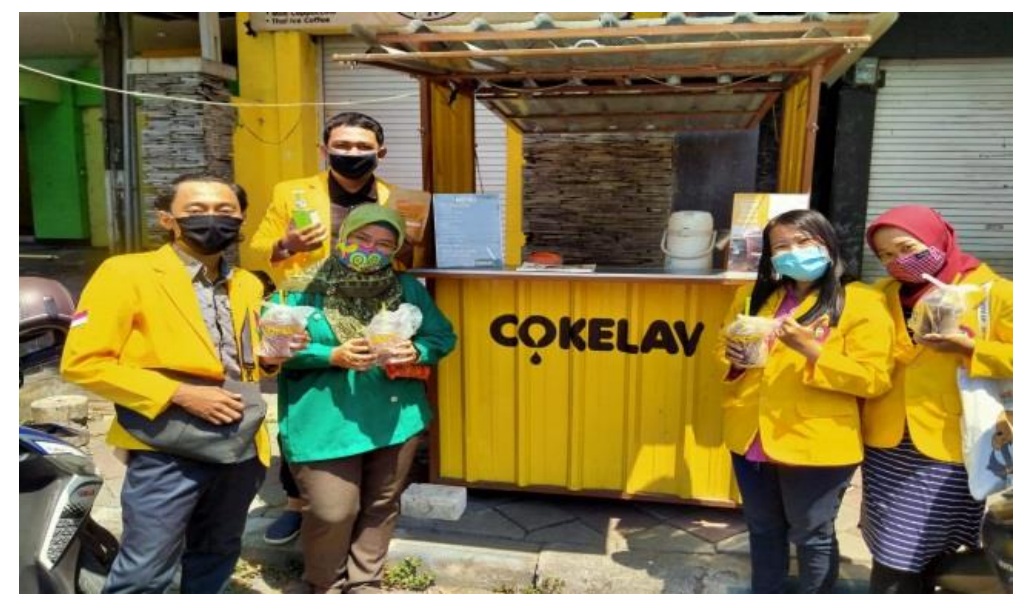

Gambar 2. Pendampingan ke salah satu mitra

Sumber : Penulis, 2020

\section{KESIMPULAN}

Kesimpulan kegiatan pengabdian kepada masyarakat ini adalah 12 mitra UMKM telah memperoleh pelatihan dan pendampingan untuk meningkatkan sistem Digital Marketing dan Sistem Informasi Akuntansi. Program yang diikuti mitra diharapkan mampu mendorong kekuatan UMKM dalam menghadapi pandemi COVID-19 yang berdampak pada penjualan dan arus kas bisnis yang terganggu. Dengan adanya program pendampingan ini UMKM memperoleh kemampuan untuk menyusun berbagai strategi bisnis baik jangka pendek maupun jangka panjang berupa pembuatan konten promosi pada media digital, strategi pemasaran 
produk yang bersaing dengan penggunaan sistem informasi akuntansi yang diaplikasikan pada bisnis mitra UMKM.

\section{DAFTAR PUSTAKA}

Undang-Undang (UU) Republik Indonesia Nomor 20 Tahun 2008 tentang UMKM

www.jemberkab.go.id. Profil Kabupaten Jember. Diakses pada 17 September 2020.

www.depkop.go.id. Data UMKM tahun 2017-2018. Diakses pada 17 September 2020. 